\title{
The experience of the National Institute for Infectious Diseases "Prof. Dr. Matei Balş" in bacterial resettlement therapy trough fecal microbiota transplant in recurrent infections with $C$. difficile
}

\author{
Cătălin Apostolescu*, Loredana Benea, Valeriu Gheorghiță, Adina Ilie, Cristina Tenea \\ From The 10th Edition of the Scientific Days of the National Institute for Infectious Diseases "Prof Dr Matei Bals" \\ Bucharest, Romania. 15-17 October 2014
}

\section{Background}

The increasing frequency of $C$. difficile infections and the increased frequency of relapses imposed implementation of new treatment alternatives.

\section{Methods}

Starting with July 2013, in the National Institute for Infectious Diseases "Prof. Dr. Matei Balş" we performed 32 therapies in patients with relapsing infections trough bacterial re-colonization.

\section{Results}

We used as donors blood relatives (children, grandchildren) in $68.8 \%$ and in $31.2 \%$ cases we used stools from others. The success rate at 90 days was $96.8 \%$. This success rate was achieved with a single procedure in $74.1 \%$ of cases, with two procedures in $22.5 \%$ and in $3.2 \%$ of cases with three procedures. The success rate was significantly higher in the first group.

\section{Conclusion}

Although the success of this maneuver is significantly higher than the standard antibiotic treatment, there is need to deepen the experience before generalizing it.

Published: 15 October 2014

\footnotetext{
* Correspondence: inkidoc@yahoo.com
}

National Institute for Infectious Diseases "Prof. Dr. Matei Balş", Bucharest, Romania

C 2014 Apostolescu et al; licensee BioMed Central Ltd. This is an Open Access article distributed under the terms of the Creative Commons Attribution License (http://creativecommons.org/licenses/by/4.0), which permits unrestricted use, distribution, and reproduction in any medium, provided the original work is properly cited. The Creative Commons Public Domain Dedication waiver (http://creativecommons.org/publicdomain/zero/1.0/) applies to the data made available in this article, unless otherwise stated.
doi:10.1186/1471-2334-14-S7-032

Cite this article as: Apostolescu et al:: The experience of the National Institute for Infectious Diseases "Prof. Dr. Matei Balş" in bacterial resettlement therapy trough fecal microbiota transplant in recurrent infections with C. difficile. BMC Infectious Diseases 2014 14(Suppl 7):032.
Submit your next manuscript to BioMed Central and take full advantage of:

- Convenient online submission

- Thorough peer review

- No space constraints or color figure charges

- Immediate publication on acceptance

- Inclusion in PubMed, CAS, Scopus and Google Scholar

- Research which is freely available for redistribution

Submit your manuscript at
www.biomedcentral.com/submit

C BioMed Central 